\title{
Nitric Oxide Sensors for Biological Applications
}

\author{
Nicole M. Iverson *, Eric M. Hofferber and Joseph A. Stapleton \\ Department of Biological Systems Engineering, University of Nebraska Lincoln, 233 Chase Hall, \\ Lincoln, NE 68583, USA; Hofferber.Eric@gmail.com (E.M.H.); JStapleton346@gmail.com (J.A.S.) \\ * Correspondence: Iverson@unl.edu; Tel.: +1-402-472-0884
}

Received: 19 December 2017; Accepted: 26 January 2018; Published: 9 February 2018

\begin{abstract}
Nitric oxide (NO) is an essential signaling molecule within biological systems and is believed to be involved in numerous diseases. As a result of NO's high reaction rate, the detection of the concentration of NO, let alone the presence or absence of the molecule, is extremely difficult. Researchers have developed multiple assays and probes in an attempt to quantify NO within biological solutions, each of which has advantages and disadvantages. This review highlights many of the current NO sensors, from those that are commercially available to the newest sensors being optimized in research labs, to assist in the understanding and utilization of NO sensors in biological fields.
\end{abstract}

Keywords: nitric oxide; sensors; biomedical engineering

\section{Introduction}

Nitric oxide (NO) is a molecule that has recently attracted heightened interest due to its vast role in human health and biology. Nearly 35 years ago NO was identified as an endothelial relaxing factor, a discovery which garnered Robert F. Furchgott, Ferid Murad, and Louis J. Ignarro a Nobel prize for medicine or physiology in 1998 [1]. However, in the past 20 years NO has also been shown to play a significant role in a multitude of physiological systems including the central nervous system (CNS), the cardiovascular system, the gastrointestinal tract, the immune system, and the renal system [2-6].

Within the CNS, NO acts as a neurotransmitter, and it has been shown to regulate feelings of pain, appetite, the sleep-wake cycle, thermoregulation, synaptic plasticity, and neural secretion [2,7-13]. NO may also act as a neuroprotective or degradative agent, depending upon its concentration within the surrounding tissue [2,14-16]. Aside from its aforementioned role in vasodilation, NO also plays a significant role in the modulation of platelet aggregation, smooth muscle cell proliferation, and LDL (low density lipoprotein) cholesterol oxidation within the cardiovascular system [1,17-19].

Within the gastrointestinal tract, NO protects the stomach epithelium by stimulating mucosal and bicarbonate secretions $[4,20,21]$. NO may also confer protection to the mucosal layer by inhibiting gastric acid secretion and leukocyte adhesion to the epithelium [4,5,22,23].

The role of NO within the immune system is immense, and while much is known about some specific roles of NO, its behavior outside of norms is still largely uncharted. A well-known role of $\mathrm{NO}$ within the immune system is its antitumor and microbial effects. Macrophage-derived NO can cause tumor cells senescence or death $[5,24]$. Cytotoxic lymphocytes can also induce NO expression within tumor cells via interferon- $\gamma$ and tumor necrosis factor (TNF), again resulting in senescence or death $[5,25]$. Paradoxically, it is not uncommon for tumor cells to constitutively express NO, aiding in tumor growth by increasing neovascularization and upregulating the production of DNA dependent protein kinases (DNA-PKcs), which are required for DNA repair $[5,26,27]$. In addition to antitumor effects, NO has been shown to display significant antimicrobial properties and its expression by immune and epithelial cells has been shown to decrease replication and kill infectious agents $[5,28]$. 
In the renal system, $\mathrm{NO}$ is principally responsible for regulating blood pressure and flow to the kidneys [29]. NO has also been implicated in natriuresis and diuresis due to its ability to inhibit sodium transport within the nephron [6].

As a result of NO's widespread impact on cell and tissue health, there are also numerous inflammatory diseases linked to the altered expression of $\mathrm{NO}$ [30-34]. There are both disease-promoting and disease-inhibiting reactions in the tumor microenvironment that are associated with changes in $\mathrm{NO}$ concentration, which has resulted in confusion about the role of NO during disease progression [35-37]. An example of this can be seen with melanoma, a type of skin cancer, in which different researchers have shown that nitric oxide synthase (NOS) and NO are both directly and inversely correlated to apoptosis, metastasis, and disease progression [38-41].

Unsurprisingly, NO's diverse effect on numerous bodily functions has led some working in the field of human health to utilize NO in the development of new medical techniques and practices. Some more notable accomplishments utilizing NO include a reversal of hypoxic pulmonary vasoconstriction using inhaled NO, the development of an antimicrobial sol-gel for coating biomaterials used in implants, and an electrochemical oxygen probe which uses $\mathrm{NO}$ as an anticlotting agent [42-44].

NO's reactivity, one of the traits that makes it such an effective signaling molecule, also makes it extremely difficult to quantify $[45,46]$. The half-life of NO is largely dependent on the microenvironment into which it is released. Environments low in available bioreactive molecules will increase the half-life of NO substantially. As a result, great discrepancies exist in the accepted biological half-life of NO [47-49]. However, the generally accepted half-life for NO in blood is $0.05-1$ millisecond [34,50-54], breaking down into multiple stable and non-stable molecules (Figure 1) [50,55-57]. When NO's reactivity rate is combined with its synthesis through NOS, a complicated biological system is created which cannot easily be understood.

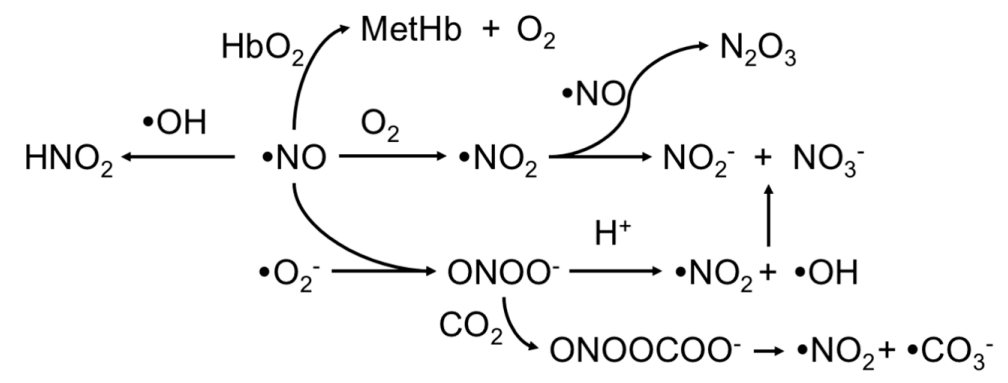

Figure 1. Nitric oxide (NO) has a very high reaction rate. Some of the pathways in the development and degradation of $\mathrm{NO}$ are shown [50,55-57].

Before the importance of NO in biological systems can be fully understood, a sensor to detect and quantify NO needs to be developed. There are multiple sensors currently on the market or being developed in research labs, all of which have their own advantages and disadvantages. This review will cover some of the main NO sensors currently in use and in development in an attempt to elucidate the areas of sensor development success and the areas in which further research is still needed.

\section{Upstream and Downstream Measurements}

Because of NO's high reactivity rate, examining upstream or downstream indicators of NO is a popular method to estimate NO concentration within samples. The Griess assay (Promega, Madison, WI, USA) determines nitrite concentration, since it is a stable byproduct of NO, and can be utilized to calculate the concentration of NO that was present in a sample before degradation occurred. The Griess test was originally published by Peter Griess in 1879 and many alterations have been made to create the current commercially available assay, although it still relies upon the diazotization reaction that Griess originally described [58]. The Griess test is relatively simple, requiring the addition of sulfanilamide in phosphoric acid and then N-1-napthylethylenediamine dihydrochloride to the samples of interest, 
as depicted in Figure 2 [59]. The solution will change color due to the azo compound and absorbance measurements can be compared to a standard to determine the concentration of nitrite in the samples.

The Griess method uses standard biology- and chemistry-based methods in combination with instruments that are commercially available. Unfortunately, these assays only make an approximation of the NO level within a solution, a problem that has led researchers to find contradictory results when comparing the predicted NO levels through different analysis methods [60].

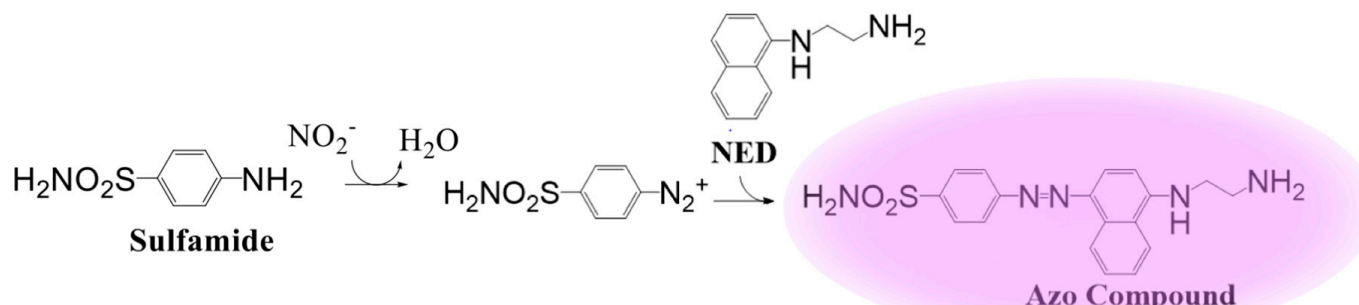

Figure 2. The Griess assay that is currently commercially available from Promega has undergone many changes and optimizations, but the diazotization reaction published by Griess is still the central component of the Griess test $[58,59]$.

An alternate method of predicting NO concentration within a system is performed by examining upstream components such as NOS activity. First characterized in 1989 [61], NOS is found in three different forms within the body which are named after the location the enzyme was originally discovered: neuronal, inducible, and endothelial NOS (nNOS, iNOS, and eNOS) [62-64]. All three isoforms of NOS utilize L-arginine as a substrate, with reduced nicotinamide-adenine-dinucleotide phosphate (NADPH) and oxygen as co-substrates to produce $\mathrm{NO}$ and citrulline as a byproduct, as shown in Figure $3[61,65,66]$. Detection of the concentration of $\left[{ }^{3} \mathrm{H}\right]$ citrulline created in the presence of $\left[{ }^{3} \mathrm{H}\right]$ arginine through liquid scintillation spectroscopy is a straightforward assay used to measure NO synthesis [67]. Bredt and Snyder state that their measurements were performed through a "simple, sensitive, and specific assay" [67] and they received results that were similar through repeated trials, supporting their claims. Unfortunately, the use of radiolabeled molecules adds a level of complication that many labs find undesirable. Advancement in the field has led to colorimetric and fluorometric assays for citrulline from labeled L-arginine, and many kits are available commercially (e.g., Abcam or Cayman Chemical). However, these assays cannot reliably be used for in vivo systems since the body's natural arginine supplies would interfere with the readings. Additionally, these assays suffer from an inability to produce localized measurements. While the assays can inform a researcher about the NO that is being produced in an entire system, they are not able to identify the specific areas of NO production and use throughout a cell or throughout a system of multiple cells.
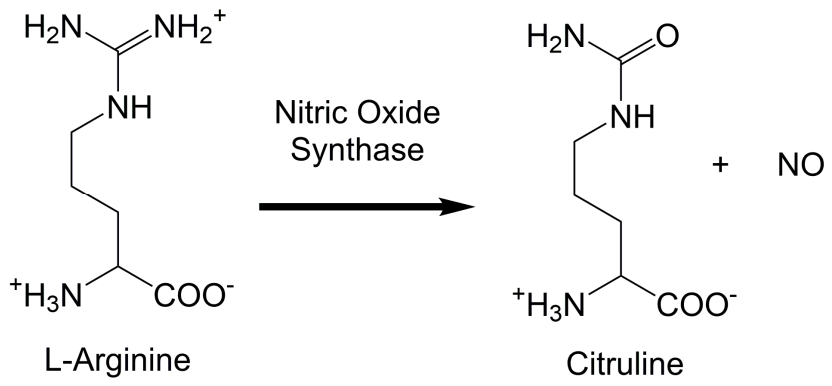

Figure 3. The nitric oxide synthase (NOS) system can be probed to approximate the concentration of nitric oxide (NO) being produced $[61,66]$. 
S-nitrosothiol (RSNO) is another upstream compound that is utilized to calculate NO concentration, since it is believed that RSNOs can act as reservoirs or carriers of NO within biological systems without altering NO's activity $[52,68,69]$. The Meyerhoff lab has shown the use of sensors that can reversibly detect RSNO within blood for a 10-day period, extending the timeframe for NO detection past most of the other sensor options [70]. The downside of this sensor is that it is detecting an upstream component of $\mathrm{NO}$ and not actual $\mathrm{NO}$ concentrations.

\section{Electrochemical Detection}

Electrochemical sensors are an excellent alternative for researchers that desire a fast and relatively simple method of determining NO concentration. In 1992, Malinski and Taha demonstrated the ability of their electrochemical probe, created by covering carbon fibers with polymeric porphyrin followed by a Nafion coating, to detect NO released from a single cell [71]. The Nafion coating was essential in the probe development since it is negatively charged and allows NO to pass through the coating while blocking the passage of nitrite and nitrate, two main downstream components of NO, to the sensor [71]. Shortly thereafter, Malinski's lab showed the ability of an electrochemical probe to detect NO within the vasculature of a living human and demonstrated dose dependent changes with their system [72].

Since the original development of the electrochemical NO sensor, commercialization has led to relatively inexpensive, user-friendly instruments consisting of various materials and allowing for real-time in vitro and in vivo measurements of $\mathrm{NO}$ within a solution. One of the commercially available systems is amiNO (produced by Innovative Instruments, Inc., Tampa, FL, USA), which allows consumers to choose the size, flexibility, durability, sensitivity, and response time for their system, has a detection limit of $1 \mathrm{nM}$ of NO, and can differentiate between $10 \mathrm{nM}$ and $11 \mathrm{nM}$ solutions [73]. Two substantial drawbacks of the electrochemical sensor are that it has not been miniaturized to the point of providing information about NO concentrations throughout a cell and it is not a sensor that can monitor NO over long time intervals while a subject is carrying out natural activities, both of which would be extremely valuable in understanding NO's physiological importance.

\section{Chemiluminescent Probes}

Chemiluminescent probes can be used to detect NO in both liquid and gaseous samples [74-77]. The general scheme for the detection of $\mathrm{NO}$ in fluid samples via chemiluminescence is through the activation of guanylyl cyclase by NO exposure, causing guanosine triphosphate (GTP) to be converted to guanosine $3^{\prime}, 5^{\prime}$-cyclic monophosphate (cGMP) which results in the release of pyrophosphate, which can then interact with adenosine triphosphate sulfurylase (ATP-sulfurylase) to form ATP [76,77]. The ATP that is formed through this series of reactions is then able to interact with a luciferin-luciferase system to emit light at $560 \mathrm{~nm}[76,77]$. An advantage of the chemiluminescent system is that it is able to detect $\mathrm{NO}$ at $\mathrm{nM}$ concentrations, since the initial guanylyl cyclase interaction with NO leads to a 200-fold linear increase [76,77]. Chemiluminescent probes have some disadvantages, including the inability to detect $\mathrm{NO}$ in vivo.

\section{Fluorescence Probes}

Fluorescence detection methods are an attractive alternative to the previously mentioned sensors because of their ability to detect both extracellular and intracellular NO as well as their ability to provide both spatial and temporal information [78]. Various types of fluorescent NO sensors have been developed, including $o$-diamino aromatic compounds, luminescent lanthanide complexes, transition-metal complexes, quantum dots, and carbon nanotube sensors. Each type of fluorescent sensor has different positive and negative traits; in the following, some of the major fluorescent sensors are listed with a discussion of their benefits and drawbacks.

A common approach for the generation of $\mathrm{NO}$ sensors is through the use of $o$-diamino aromatic molecules (as depicted in Figure 4) such as 4,5-diaminofluorescein, commonly known as DAF-2 [79-82]. 
Unfortunately, many of the $o$-diamino sensors have drawbacks, including a false positive signal when exposed to dehydroascorbic acid (DHA) and ascorbic acid (AA), which often co-localize with NO synthase, and a sensitivity to $\mathrm{pH}$ [83-85]. The Shear research group developed a new NO sensor in 2010, named $\mathrm{NO}_{550}$, that has a high specificity, does not react to co-localized proteins, and is not sensitive to $\mathrm{pH}$ differences, which is advantageous since various intracellular compartments have different $\mathrm{pH}$ values [86-88]. $\mathrm{NO}_{550}$ shows a red-shifted 1500-fold increase in fluorescence and does not react to other reactive oxygen and nitrogen species [88]. One drawback of $\mathrm{NO}_{550}$ is that it has limited aqueous solubility, making it less than ideal for biological studies [88].

An alternate method for NO fluorescence detection is through the use of transition metal-based complexes, which create a turn-on fluorescent signal. For transition metal-based complexes a fluorophore is bound to a transition metal and exhibits a very weak signal, but a reaction with NO causes the displacement of the fluorophore and fluorescence recovery [89,90]. Unfortunately, metal-based complexes are water-insoluble creating a good NO sensor for organic solvents but not being optimal for many biological scenarios [91].

Because aqueous solubility is believed to be an important characteristic for biological sensors, Nagano's group developed a luminescent lanthanide complex that showed a 50-fold increase in luminescence (excitation $500 \mathrm{~nm}$ and emission $980 \mathrm{~nm}$ ) after exposure to $50 \mathrm{uM}$ aqueous NO [92]. A benefit of Nagano's sensor over previously developed $\mathrm{Yb}^{3+}$ complexes lies in the fact that their probe is functional in aqueous systems, has an excitation wavelength that can be produced via two-photon technology, and has an emission wavelength in the near-infrared region, where water and blood absorb minimal light [92].

In 2017, a new fluorescent NO sensor called NCNO, which is based on N-nitrosation reactivity was developed to avoid non-specific reactions from DHA, AA, and reactive oxygen species [93]. NCNO covalently binds a two-photon fluorophore to a mono alkyl-substituted p-phenylenediamine, as shown in Figure 4 [93]. Because the two-photon fluorophore has an emission wavelength greater than $600 \mathrm{~nm}$, the NCNO probe can be detected deep within tissue and has been shown to detect NO generation in an ischemia reperfusion injury mouse model [93]. One of the shortcomings of the NCNO detection system is that $\mathrm{N}$-nitrosation is detected, not total $\mathrm{NO}$ concentration, so assumptions and models need to be used to determine the actual NO concentration in the solution/tissue.

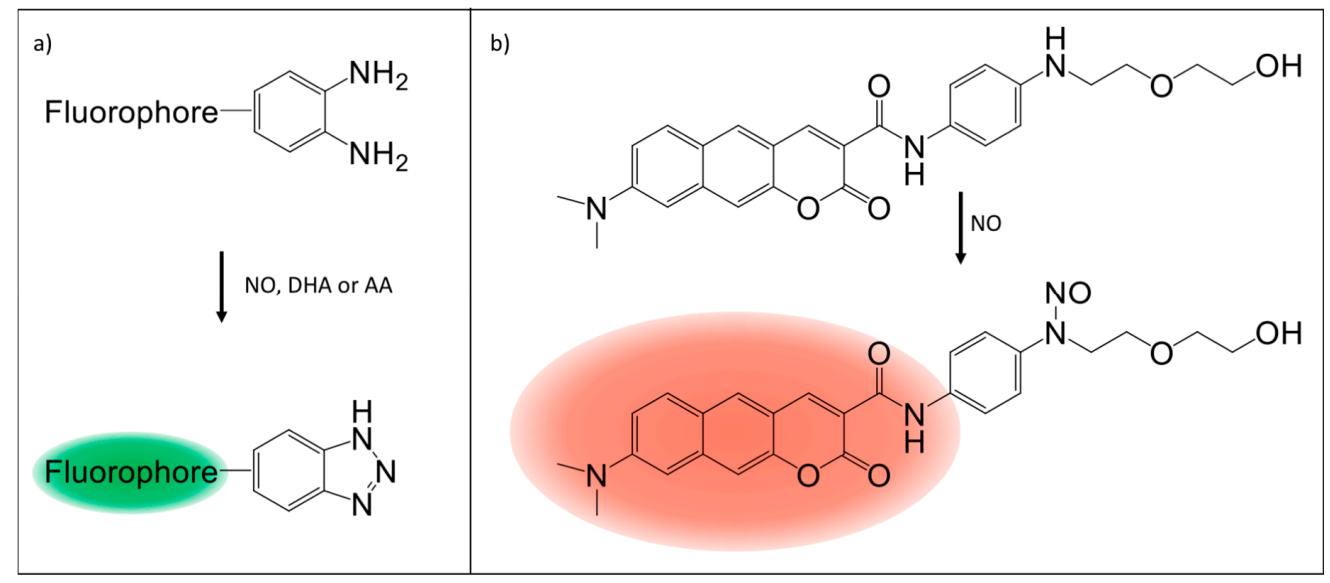

Figure 4. Comparison of a common $o$-diamino aromatic probe with the new NCNO probe. (a) shows a generic $o$-diamino aromatic probe that is activated by exposure to nitric oxide (NO), dehydroascorbic acid (DHA), or ascorbic acid (AA); (b) shows the NCNO probe that is also activated by NO, but not by DHA or AA [93].

Quantum dots (QDs) are a class of nanoparticles that can fluoresce at many different wavelengths (with narrow emission spectra), do not quickly photobleach, and emit light more than 100 times stronger than organic dyes [91,94]. Quantum dots have been shown to be excellent turn on/off 
chemosensors for various analytes through the attachment of analyte-sensitive molecules to the QD's surface. A recent turn on fluorescence sensor for NO, called Fe(III)-QD-nanoprobe, was developed with CdSe-ZnS QDs providing the base/fluorescent portion of the sensor and tris(dithiocarbamato)iron(III) acting as the NO responsive molecules [95]. The Fe(III)-QD-nanoprobe exhibited a dose-dependent response to NO that was stable for over an hour and specificity to NO when compared to nitrite, nitrate, and other reactive oxygen/nitrogen species [95]. Unfortunately, the Fe(III)-QD-nanoprobe is irreversibly altered by exposure to $\mathrm{NO}$ and can therefore only be used for a single trial. Yet, since this was the first published example of a QD sensor for $\mathrm{NO}$, it is possible that further optimization will allow the sensor to recover and be used for multiple cycles [95].

Carbon nanotubes are another class of nanoparticles that have recently been shown to act as a biological sensor [96-98]. Carbon nanotubes are a diverse group of particles that perform differently depending on their chirality (the angle of their carbon bonds in relation to the tube's direction) $[99,100]$. Semiconducting single-wall carbon nanotubes (SWNT) are one-dimensional, pure carbon substances that fluoresce in the near-infrared region (900-1500 nm) when excited by visible light $(500-850 \mathrm{~nm})[99,101]$. The wavelength at which SWNT fluoresce (with a narrow emission spectrum) is dependent on their chirality, and therefore, similar to QDs, multiple SWNT can be differentiated within a single solution [101,102]. The Strano research group developed NO sensors by wrapping SWNT with specific polymers, including 3,4-diaminophenyl-functionalized dextran or short oligonucleotide sequences such as $(\mathrm{AAAT})_{7}$ and $(\mathrm{AT})_{15}$, that display a change in fluorescence intensity when exposed to $\mathrm{NO}$, as depicted in Figure 5 [103-105]. The SWNT sensors have many advantages over other fluorescence sensors including the lack of photobleaching, ability to be detected by Raman scattering in addition to their fluorescent signal, and emission in the near infrared range where blood and water do not absorb a large percent of light [106-109]. A shortcoming of the current SWNT-based NO sensors is that they are turn off fluorescence sensors, adding a layer of difficulty to the long-term detection of NO within a system [103-105].

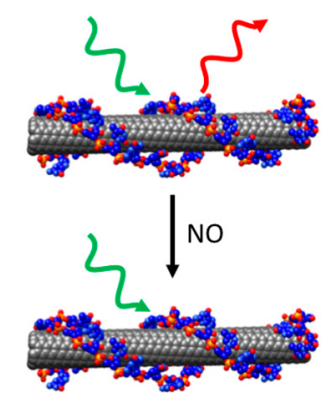

Figure 5. Schematic of a single wall carbon nanotube sensor for nitric oxide (NO) detection. The nanotube is excited by a $561 \mathrm{~nm}$ laser and emits $990 \mathrm{~nm}$ fluorescence when there is no NO present, but when NO is added to the system the fluorescence of the carbon nanotube is quenched [104,105].

\section{Genetic Biosensors}

An interesting new way to detect NO within a single cell is through the addition of genetic materials that will code for a visual signal response in the presence of NO [110]. Ronald Malli and colleagues developed a system in which the NO responsive transcription factor of Escherichia coli (E. coli) is conjugated to fluorescent protein variants that are then taken up by cells [110-112]. When these fluorescent probes were tested with HeLa cells they were shown to be taken up and expressed at similar rates compared to other genetically encoded probes [110]. The NO probes were shown to respond to NO immediately with a reversible signal, allowing for long term NO dynamics investigations within cells in vitro [110]. Ongoing research efforts are looking at the possibility of utilizing this system to develop an in vivo model [110]. One major obstacle that still prevents the utilization of the probes in vivo is that the fluorescence emission range that is currently being utilized is difficult to visualize at any depth within tissue. 
Table 1. Overview of the nitric oxide (NO) sensing methods discussed in this review with the assay/instruments' molecule and rate of detection, sensitivity, scale, strengths and current drawbacks outlined.

\begin{tabular}{|c|c|c|c|c|c|c|c|}
\hline Detection Method & Sensitivity & Molecule Detected & Rate of Detection & Scale & In Vivo, In Vitro, Both & Strengths & Drawbacks \\
\hline Griess Assay [58-60] & $1.0 \mu \mathrm{M}$ & $\mathrm{NO}_{2}$ & End-Point & System & In Vitro & $\begin{array}{c}\text { Availability, } \mathrm{NO}_{2} \text { is stable and } \\
\text { provides an estimate of } \mathrm{NO} \text { in } \\
\text { the system }\end{array}$ & $\begin{array}{c}\text { Does not detect NO directly, } \\
\text { inconsistent results from system } \\
\text { to system }\end{array}$ \\
\hline NOS Activity Assay $[61,67]$ & $5.0 \mu \mathrm{U}$ & L-Citrulline & End-Point & System & In Vitro & $\begin{array}{c}\text { Availability, L-citrulline is stable } \\
\text { and estimates NO generated } \\
\text { by NOS }\end{array}$ & $\begin{array}{l}\text { Does not detect NO directly, } \\
\text { natural L-arginine sources will } \\
\text { interfere with readings }\end{array}$ \\
\hline Electrochemical Probe [71-73] & $1.0 \mathrm{nM}$ & NO & Real-Time & System & Both & $\begin{array}{c}\text { Availability, Real-time detection, } \\
\text { High sensitivity }\end{array}$ & $\begin{array}{l}\text { Detects on a system level, cannot } \\
\text { detect over long time intervals }\end{array}$ \\
\hline $\begin{array}{c}\text { Chemiluminescent } \\
\text { Probes }[76,77]\end{array}$ & $50 \mathrm{pM}$ & NO & End-Point & System & In Vitro & High sensitivity to NO & $\begin{array}{c}\text { Detects on a system level, Cannot } \\
\text { detect in vivo }\end{array}$ \\
\hline $\begin{array}{c}o \text {-diamino Aromatic } \\
\text { Compounds }[83,86,88]\end{array}$ & $5.0 \mu \mathrm{M}$ & NO & Real-Time & Single Cell & In Vitro & $\begin{array}{c}\text { Real-time detection of NO at } \\
\text { a cellular level }\end{array}$ & $\begin{array}{l}\text { Limited aqueous solubility, false } \\
\text { positives with DHA and AA }\end{array}$ \\
\hline $\begin{array}{l}\text { Luminescent Lanthanide } \\
\text { Complexes [92] }\end{array}$ & $\sim 0.5 \mu \mathrm{M}$ & NO, N-Nitrosation & Real-Time & Single Cell & Both & $\begin{array}{c}\text { Real-time detection at } \\
\text { a cellular level }\end{array}$ & Does not detect NO directly \\
\hline $\begin{array}{c}\text { Transition-Metal } \\
\text { Complexes [90,91] } \\
\end{array}$ & $4.0 \mu \mathrm{M}$ & NO & Real-Time & System & In Vitro & $\begin{array}{l}\text { Sensitivity, real-time detection } \\
\text { of NO }\end{array}$ & Limited aqueous solubility \\
\hline Quantum Dots [95] & $3.3 \mu \mathrm{M}$ & NO & Real-Time & Single Cell & Both & $\begin{array}{l}\text { Real-time detection of NO at } \\
\text { a cellular level }\end{array}$ & Irreversibly altered by $\mathrm{NO}$ \\
\hline Carbon Nanotubes [103-105] & $1.0 \mu \mathrm{M}$ & NO & Real-Time & Single Cell & Both & $\begin{array}{c}\text { Real-time detection of NO at } \\
\text { a cellular level }\end{array}$ & Turn off sensing of NO \\
\hline Genetic Biosensors [110] & $50-94 \mathrm{nM}$ & NO & Real-Time & Single Cell & In Vitro & $\begin{array}{c}\text { Real-time detection of NO at } \\
\text { a cellular level }\end{array}$ & $\begin{array}{l}\text { Fluorescence emission is not } \\
\text { detectable through tissue }\end{array}$ \\
\hline
\end{tabular}




\section{Conclusions}

Nitric oxide is an essential reactive species within biological systems. As researchers are able to understand the many complex reactions associated with $\mathrm{NO}$, a deeper understanding of healthy and diseased cells, tissues, and organisms will be uncovered. Before researchers can understand NO's role in biological functions there must be a way to accurately measure NO both in vitro and in vivo. Current sensor methods, many of which are outlined in Table 1, are greatly improved over those from just 10 or 20 years ago, and hopefully further progress can be made within the coming years.

Acknowledgments: The Iverson Lab would like to thank the Nebraska Center for Integrated Biomolecular Communication (NIH National Institutes of General Medical Sciences P20-GM113126) for funding support.

Conflicts of Interest: The authors declare no conflict of interest.

\section{References}

1. Yetik-Anacak, G.; Catravas, J.D. Nitric oxide and the endothelium: History and impact on cardiovascular disease. Vasc. Pharmacol. 2006, 45, 268-276. [CrossRef] [PubMed]

2. Calabrese, V.; Mancuso, C.; Calvani, M.; Rizzarelli, E.; Butterfield, D.A.; Giuffrida Stella, A.M. Nitric oxide in the central nervous system: Neuroprotection versus neurotoxicity. Nat. Rev. Neurosci. 2007, 8, 766. [CrossRef] [PubMed]

3. Loscalzo, J.; Welch, G. Nitric oxide and its role in the cardiovascular system. Prog. Cardiovasc. Dis. 1995, 38, 87-104. [CrossRef]

4. Lanas, A. Role of nitric oxide in the gastrointestinal tract. Arthritis Res. Ther. 2008, 10, S4. [CrossRef] [PubMed]

5. Bogdan, C. Nitric oxide and the immune response. Nat. Immunol. 2001, 2, 907-916. [CrossRef] [PubMed]

6. Mount, P.F.; Power, D.A. Nitric oxide in the kidney: Functions and regulation of synthesis. Acta Physiol. 2006, 187, 433-446. [CrossRef] [PubMed]

7. Yamamoto, T.; Shimoyama, N.; Mizuguchi, T. Nitric oxide synthase inhibitor blocks spinal sensitization induced by formalin injection into the rat paw. Anesth. Analg. 1993, 77, 886-890. [CrossRef] [PubMed]

8. Morley, J.E.; Farr, S.A.; Sell, R.L.; Hileman, S.M.; Banks, W.A. Nitric oxide is a central component in neuropeptide regulation of appetite. Peptides 2011, 32, 776-780. [CrossRef] [PubMed]

9. Monti, J.M.; Jantos, H. Effects of L-arginine and SIN-1 on sleep and waking in the rat during both phases of the light-dark cycle. Life Sci. 2004, 75, 2027-2034. [CrossRef] [PubMed]

10. Lacerda, A.C.R.; Marubayashi, U.; Coimbra, C.C. Nitric oxide pathway is an important modulator of heat loss in rats during exercise. Brain Res. Bull. 2005, 67, 110-116. [CrossRef] [PubMed]

11. Bon, C.L.M.; Garthwaite, J. On the Role of Nitric Oxide in Hippocampal Long-Term Potentiation. J. Neurosci. 2003, 23, 1941-1948. [PubMed]

12. Dinerman, J.L.; Dawson, T.M.; Schell, M.J.; Snowman, A.; Snyder, S.H. Endothelial nitric oxide synthase localized to hippocampal pyramidal cells: Implications for synaptic plasticity. Proc. Natl. Acad. Sci. USA 1994, 91, 4214-4218. [CrossRef] [PubMed]

13. Stern, J.E. Nitric oxide and homeostatic control: An intercellular signalling molecule contributing to autonomic and neuroendocrine integration? Prog. Biophys. Mol. Biol. 2004, 84, 197-215. [CrossRef] [PubMed]

14. Contestabile, A.; Ciani, E. Role of nitric oxide in the regulation of neuronal proliferation, survival and differentiation. Neurochem. Int. 2004, 45, 903-914. [CrossRef] [PubMed]

15. Riccio, A.; Alvania, R.S.; Lonze, B.E.; Ramanan, N.; Kim, T.; Huang, Y.; Dawson, T.M.; Snyder, S.H.; Ginty, D.D. A nitric oxide signaling pathway controls CREB-mediated gene expression in neurons. Mol. Cell 2006, 21, 283-294. [CrossRef] [PubMed]

16. Pacher, P.; Beckman, J.S.; Liaudet, L. Nitric oxide and peroxynitrite in health and disease. Physiol. Rev. 2007, 87, 315-424. [CrossRef] [PubMed]

17. Wang, G.-R.; Zhu, Y.; Halushka, P.V.; Lincoln, T.M.; Mendelsohn, M.E. Mechanism of platelet inhibition by nitric oxide: In vivo phosphorylation of thromboxane receptor by cyclic GMP-dependent protein kinase. Proc. Natl. Acad. Sci. USA 1998, 95, 4888-4893. [CrossRef] [PubMed] 
18. Garg, U.C.; Hassid, A. Nitric oxide-generating vasodilators and 8-bromo-cyclic guanosine monophosphate inhibit mitogenesis and proliferation of cultured rat vascular smooth muscle cells. J. Clin. Investig. 1989, 83, 1774-1777. [CrossRef] [PubMed]

19. Chen, L.Y.; Mehta, P.; Mehta, J.L. Oxidized LDL decreases L-arginine uptake and nitric oxide synthase protein expression in human platelets: Relevance of the effect of oxidized LDL on platelet function. Circulation 1996, 93, 1740-1746. [CrossRef] [PubMed]

20. Brown, J.F.; Keates, A.C.; Hanson, P.J.; Whittle, B.J. Nitric oxide generators and cGMP stimulate mucus secretion by rat gastric mucosal cells. Am. J. Physiol. 1993, 265, G418-G422. [CrossRef] [PubMed]

21. Wallace, J.L.; Tigley, A.W. Review article: New insights into prostaglandins and mucosal defence. Aliment. Pharmacol. Ther. 1995, 9, 227-235. [CrossRef] [PubMed]

22. Kubes, P.; Suzuki, M.; Granger, D.N. Nitric oxide: An endogenous modulator of leukocyte adhesion. Proc. Natl. Acad. Sci. USA 1991, 88, 4651-4655. [CrossRef] [PubMed]

23. Berg, A.; Redeen, S.; Grenegard, M.; Ericson, A.C.; Sjostrand, S.E. Nitric oxide inhibits gastric acid secretion by increasing intraparietal cell levels of cGMP in isolated human gastric glands. Am. J. Physiol. Gastrointest. Liver Physiol. 2005, 289, G1061-1066. [CrossRef] [PubMed]

24. Nathan, C. Nitric oxide as a secretory product of mammalian cells. FASEB J. 1992, 6, 3051-3064. [CrossRef] [PubMed]

25. Kwak, J.Y.; Han, M.K.; Choi, K.S.; Park, I.H.; Park, S.Y.; Sohn, M.H.; Kim, U.H.; McGregor, J.R.; Samlowski, W.E.; Yim, C.Y. Cytokines secreted by lymphokine-activated killer cells induce endogenous nitric oxide synthesis and apoptosis in DLD-1 colon cancer cells. Cell. Immunol. 2000, 203, 84-94. [CrossRef] [PubMed]

26. Bogdan, C. The Function of Nitric Oxide in the Immune System in Nitric Oxide; Springer: Heidelberg, Germany, 2000.

27. Xu, W.; Liu, L.; Smith, G.C.M.; Charles, 1.G. Nitric oxide upregulates expression of DNA-PKcs to protect cells from DNA-damaging anti-tumour agents. Nat. Cell Biol. 2000, 2, 339. [CrossRef] [PubMed]

28. Jones, M.L.; Ganopolsky, J.G.; Labbe, A.; Wahl, C.; Prakash, S. Antimicrobial properties of nitric oxide and its application in antimicrobial formulations and medical devices. Appl. Microbiol. Biotechnol. 2010, 88, $401-407$. [CrossRef] [PubMed]

29. Majid, D.S.A.; Navar, L.G. Nitric oxide in the control of renal hemodynamics and excretory function. Am. J. Hypertens. 2001, 14, 74S-82S. [CrossRef]

30. Moncada, S.; Palmer, R.M.; Higgs, E.A. Nitric oxide: Physiology, pathophysiology, and pharmacology. Pharmacol. Rev. 1991, 43, 109-142. [PubMed]

31. Thomas, D.D.; Ridnour, L.A.; Isenberg, J.S.; Flores-Santana, W.; Switzer, C.H.; Donzelli, S.; Hussain, P.; Vecoli, C.; Paolocci, N.; Ambs, S.; et al. The chemical biology of nitric oxide: Implications in cellular signaling. Free Radic. Biol. Med. 2008, 45, 18-31. [CrossRef] [PubMed]

32. Heneka, M.T.; Kummer, M.P.; Stutz, A.; Delekate, A.; Schwartz, S.; Vieira-Saecker, A.; Griep, A.; Axt, D.; Remus, A.; Tzeng, T.C.; et al. NLRP3 is activated in Alzheimer's disease and contributes to pathology in APP/PS1 mice. Nature 2013, 493, 674-678. [CrossRef] [PubMed]

33. Ignarro, L.J. Nitric Oxide: Biology and Pathobiology; Academic Press: Cambridge, MA, USA, 2000.

34. Beckman, J.S.; Koppenol, W.H. Nitric oxide, superoxide, and peroxynitrite: The good, the bad, and ugly. Am. J. Physiol. Cell Physiol. 1996, 271, C1424-C1437. [CrossRef] [PubMed]

35. Lechner, M.; Lirk, P.; Rieder, J. Inducible nitric oxide synthase (iNOS) in tumor biology: The two sides of the same coin. Semin. Cancer Biol. 2005, 15, 277-289. [CrossRef] [PubMed]

36. Ricciardolo, F.L.M.; Sterk, P.J.; Gaston, B.; Folkerts, G. Nitric Oxide in Health and Disease of the Respiratory System. Physiol. Rev. 2004, 84, 731-765. [CrossRef] [PubMed]

37. Bogdan, C. The Multiplex Function of Nitric Oxide in (Auto)immunity. J. Exp. Med. 1998, 187, 1361-1365. [CrossRef] [PubMed]

38. Xie, K.; Huang, S.; Dong, Z.; Juang, S.H.; Gutman, M.; Xie, Q.W.; Nathan, C.; Fidler, I.J. Transfection with the inducible nitric oxide synthase gene suppresses tumorigenicity and abrogates metastasis by K-1735 murine melanoma cells. J. Exp. Med. 1995, 181, 1333-1343. [CrossRef] [PubMed]

39. Massi, D.; Franchi, A.; Sardi, I.; Magnelli, L.; Paglierani, M.; Borgognoni, L.; Maria Reali, U.; Santucci, M. Inducible nitric oxide synthase expression in benign and malignant cutaneous melanocytic lesions. J. Pathol. 2001, 194, 194-200. [CrossRef]

40. Liu, L.; Stamler, J.S. NO: An inhibitor of cell death. Cell Death Differ. 1999, 6, 937-942. [CrossRef] [PubMed] 
41. Brune, B.; von Knethen, A.; Sandau, K.B. Nitric oxide (NO): An effector of apoptosis. Cell Death Differ. 1999, 6, 969-975. [CrossRef] [PubMed]

42. Frostell, C.; Fratacci, M.D.; Wain, J.C.; Jones, R.; Zapol, W.M. Inhaled nitric oxide. A selective pulmonary vasodilator reversing hypoxic pulmonary vasoconstriction. Circulation 1991, 83, 2038-2047. [CrossRef] [PubMed]

43. Nablo, B.J.; Rothrock, A.R.; Schoenfisch, M.H. Nitric oxide-releasing sol-gels as antibacterial coatings for orthopedic implants. Biomaterials 2005, 26, 917-924. [CrossRef] [PubMed]

44. Ren, H.; Colletta, A.; Koley, D.; Wu, J.; Xi, C.; Major, T.C.; Bartlett, R.H.; Meyerhoff, M.E. Thromboresistant/anti-biofilm catheters via electrochemically modulated nitric oxide release. Bioelectrochemistry 2015, 104, 10-16. [CrossRef] [PubMed]

45. Butler, A.R.; Flitney, F.W.; Williams, D.L.H. NO, nitrosonium ions, nitroxide ions, nitrosothiols and iron-nitrosyls in biology: A chemist's perspective. Trends Pharmacol. Sci. 1995, 16, 18-22. [CrossRef]

46. Gaston, B. Nitric oxide and thiol groups. Biochim. Biophys. Acta Bioenerg. 1999, 1411, 323-333. [CrossRef]

47. Grube, R.; Kelm, M.; Motz, W.; Strauer, B. The biology of nitric oxide. Enzymol. Biochem. Immunol. 1994, 4, 201-204.

48. Liu, X.; Miller, M.J.; Joshi, M.S.; Thomas, D.D.; Lancaster, J.R. Accelerated reaction of nitric oxide with $\mathrm{O}_{2}$ within the hydrophobic interior of biological membranes. Proc. Natl. Acad. Sci. USA 1998, 95, 2175-2179. [CrossRef] [PubMed]

49. Sies, H. Oxidative stress: From basic research to clinical application. Am. J. Med. 1991, 91, S31-S38. [CrossRef]

50. Borland, C. Endothelium in control. Br. Heart J. 1991, 66, 405. [CrossRef] [PubMed]

51. Kelm, M.; Feelisch, M.; Grube, R.; Motz, W.; Strauer, B.E. The Biology of Nitric Oxide, Physiological and Clinical Aspects; Portland Press: London, UK, 1992.

52. Stamler, J.S.; Jaraki, O.; Osborne, J.; Simon, D.I.; Keaney, J.; Vita, J.; Singel, D.; Valeri, C.R.; Loscalzo, J. Nitric oxide circulates in mammalian plasma primarily as an S-nitroso adduct of serum albumin. Proc. Natl. Acad. Sci. USA 1992, 89, 7674-7677. [CrossRef] [PubMed]

53. Malinski, T.; Taha, Z.; Grunfeld, S.; Patton, S.; Kapturczak, M.; Tomboulian, P. Diffusion of nitric oxide in the aorta wall monitored in situ by porphyrinic microsensors. Biochem. Biophys. Res. Commun. 1993, 193, 1076-1082. [CrossRef] [PubMed]

54. Kelm, M.; Yoshida, K. Metabolic Fate of Nitric Oxide and Related N-Oxides; John Wiley and Sons: Chichester, UK, 1996.

55. Kelm, M. Nitric oxide metabolism and breakdown. Biochim. Biophys. Acta 1999, 1411, 273-289. [CrossRef]

56. Liu, X.; Miller, M.J.; Joshi, M.S.; Sadowska-Krowicka, H.; Clark, D.A.; Lancaster, J.R., Jr. Diffusion-limited reaction of free nitric oxide with erythrocytes. J. Biol. Chem. 1998, 273, 18709-18713. [CrossRef] [PubMed]

57. Wardman, P. The importance of radiation chemistry to radiation and free radical biology (The 2008 Silvanus Thompson Memorial Lecture). Br. J. Radiol. 2009, 82, 89-104. [CrossRef] [PubMed]

58. Griess, P. Bemerkungen zu der Abhandlung der HH. Weselsky und Benedikt Ueber einige Azoverbindungen. Ber. Deutsch. Chem. Ges. 1879, 12, 426-428. [CrossRef]

59. Promega. Griess Reagent System, Instructions for Use of Product G2930; Promega: Madison, WI, USA, 2009.

60. Burke, A.J.; Sullivan, F.J.; Giles, F.J.; Glynn, S.A. The yin and yang of nitric oxide in cancer progression. Carcinogenesis 2013, 34, 503-512. [CrossRef] [PubMed]

61. Knowles, R.G.; Palacios, M.; Palmer, R.M.; Moncada, S. Formation of nitric oxide from L-arginine in the central nervous system: A transduction mechanism for stimulation of the soluble guanylate cyclase. Proc. Natl. Acad. Sci. USA 1989, 86, 5159-5162. [CrossRef] [PubMed]

62. Nishimura, J.S.; Martasek, P.; McMillan, K.; Salerno, J.; Liu, Q.; Gross, S.S.; Masters, B.S. Modular structure of neuronal nitric oxide synthase: Localization of the arginine binding site and modulation by pterin. Biochem. Biophys. Res. Commun. 1995, 210, 288-294. [CrossRef] [PubMed]

63. Green, S.J.; Mellouk, S.; Hoffman, S.L.; Meltzer, M.S.; Nacy, C.A. Cellular mechanisms of nonspecific immunity to intracellular infection: Cytokine-induced synthesis of toxic nitrogen oxides from L-arginine by macrophages and hepatocytes. Immunol. Lett. 1990, 25, 15-19. [CrossRef]

64. Radomski, M.W.; Palmer, R.M.; Moncada, S. The anti-aggregating properties of vascular endothelium: Interactions between prostacyclin and nitric oxide. Br. J. Pharmacol. 1987, 92, 639-646. [CrossRef] [PubMed]

65. Palmer, R.M.; Ashton, D.S.; Moncada, S. Vascular endothelial cells synthesize nitric oxide from L-arginine. Nature 1988, 333, 664-666. [CrossRef] [PubMed] 
66. Hecker, M.; Sessa, W.C.; Harris, H.J.; Anggard, E.E.; Vane, J.R. The metabolism of L-arginine and its significance for the biosynthesis of endothelium-derived relaxing factor: Cultured endothelial cells recycle L-citrulline to L-arginine. Proc. Natl. Acad. Sci. USA 1990, 87, 8612-8616. [CrossRef] [PubMed]

67. Bredt, D.S.; Snyder, S.H. Isolation of nitric oxide synthetase, a calmodulin-requiring enzyme. Proc. Natl. Acad. Sci. USA 1990, 87, 682-685. [CrossRef] [PubMed]

68. Scharfstein, J.S.; Keaney, J.F.; Slivka, A.; Welch, G.N.; Vita, J.A.; Stamler, J.S.; Loscalzo, J. In vivo transfer of nitric oxide between a plasma protein-bound reservoir and low molecular weight thiols. J. Clin. Investig. 1994, 94, 1432-1439. [CrossRef] [PubMed]

69. Rassaf, T.; Kleinbongard, P.; Preik, M.; Dejam, A.; Gharini, P.; Lauer, T.; Erckenbrecht, J.; Duschin, A.; Schulz, R.; Heusch, G.; et al. Plasma nitrosothiols contribute to the systemic vasodilator effects of intravenously applied NO: Experimental and clinical Study on the fate of NO in human blood. Circ. Res. 2002, 91, 470-477. [CrossRef] [PubMed]

70. Cha, W.; Meyerhoff, M.E. S-Nitrosothiol Detection via Amperometric Nitric Oxide Sensor with Surface Modified Hydrogel Layer Containing Immobilized Organoselenium Catalyst. Langmuir 2006, 22, 10830-10836. [CrossRef] [PubMed]

71. Malinski, T.; Taha, Z. Nitric oxide release from a single cell measured in situ by a porphyrinic-based microsensor. Nature 1992, 358, 676-678. [CrossRef] [PubMed]

72. Vallance, P.; Bhagat, K.; MacAllister, R.; Patton, S.; Malinski, T.; Radomski, M.; Moncada, S. Direct measurement of nitric oxide in human beings. Lancet 1995, 346, 153-154. [CrossRef]

73. Innovative Instruments, Inc. All-Plastic Leak-Free Reference Electrode: Handles over 5 M Hydroxide and Hydrofluoric Acid. Available online: http:/ / www.2in.com/index.html (accessed on 27 November 2017).

74. Dunham, A.J.; Barkley, R.M.; Sievers, R.E. Aqueous nitrite ion determination by selective reduction and gas phase nitric oxide chemiluminescence. Anal. Chem. 1995, 67, 220-224. [CrossRef] [PubMed]

75. Michelakis, E.D.; Archer, S.L. The measurement of NO in biological systems using chemiluminescence. Meth. Mol. Biol. 1998, 100, 111-127.

76. Woldman, Y.Y.; Eubank, T.D.; Mock, A.J.; Stevens, N.C.; Varadharaj, S.; Turco, J.; Gavrilin, M.A.; Branchini, B.R.; Khramtsov, V.V. Detection of nitric oxide production in cell cultures by luciferin-luciferase chemiluminescence. Biochem. Biophys. Res. Commun. 2015, 465, 232-238. [CrossRef] [PubMed]

77. Woldman, Y.Y.; Sun, J.; Zweier, J.L.; Khramtsov, V.V. Direct chemiluminescence detection of nitric oxide in aqueous solutions using the natural nitric oxide target soluble guanylyl cyclase. Free Radic. Biol. Med. 2009, 47, 1339-1345. [CrossRef] [PubMed]

78. Ulissi, Z.W.; Sen, F.; Gong, X.; Sen, S.; Iverson, N.; Boghossian, A.A.; Godoy, L.C.; Wogan, G.N.; Mukhopadhyay, D.; Strano, M.S. Spatiotemporal Intracellular Nitric Oxide Signaling Captured Using Internalized, Near-Infrared Fluorescent Carbon Nanotube Nanosensors. Nano Lett. 2014, 14, 4887-4894. [CrossRef] [PubMed]

79. Kasim, N.; Branton, R.L.; Clarke, D.J. Neuronal nitric oxide synthase immunohistochemistry and 4,5-diaminofluorescein diacetate: Tools for nitric oxide research. J. Neurosci. Methods 2001, 112, 1-8. [CrossRef]

80. Rathel, T.R.; Leikert, J.J.; Vollmar, A.M.; Dirsch, V.M. Application of 4,5-diaminofluorescein to reliably measure nitric oxide released from endothelial cells in vitro. Biol. Proced. Online 2003, 5, 136-142. [CrossRef] [PubMed]

81. Leikert, J.F.; Rathel, T.R.; Muller, C.; Vollmar, A.M.; Dirsch, V.M. Reliable in vitro measurement of nitric oxide released from endothelial cells using low concentrations of the fluorescent probe 4,5-diaminofluorescein. FEBS Lett. 2001, 506, 131-134. [CrossRef]

82. Strijdom, H.; Muller, C.; Lochner, A. Direct intracellular nitric oxide detection in isolated adult cardiomyocytes: Flow cytometric analysis using the fluorescent probe, diaminofluorescein. J. Mol. Cell. Cardiol. 2004, 37, 897-902. [CrossRef] [PubMed]

83. Kojima, H.; Hirotani, M.; Nakatsubo, N.; Kikuchi, K.; Urano, Y.; Higuchi, T.; Hirata, Y.; Nagano, T. Bioimaging of nitric oxide with fluorescent indicators based on the rhodamine chromophore. Anal. Chem. 2001, 73, 1967-1973. [CrossRef] [PubMed]

84. Zhang, X.; Kim, W.S.; Hatcher, N.; Potgieter, K.; Moroz, L.L.; Gillette, R.; Sweedler, J.V. Interfering with nitric oxide measurements. 4,5-diaminofluorescein reacts with dehydroascorbic acid and ascorbic acid. J. Biol. Chem. 2002, 277, 48472-48478. [CrossRef] [PubMed] 
85. Ye, X.; Rubakhin, S.S.; Sweedler, J.V. Simultaneous Nitric Oxide and Dehydroascorbic Acid Imaging by Combining Diaminofluoresceins and Diaminorhodamines. J. Neurosci. Methods 2008, 168, 373-382. [CrossRef] [PubMed]

86. Kim, J.H.; Johannes, L.; Goud, B.; Antony, C.; Lingwood, C.A.; Daneman, R.; Grinstein, S. Noninvasive measurement of the $\mathrm{pH}$ of the endoplasmic reticulum at rest and during calcium release. Proc. Natl. Acad. Sci. USA 1998, 95, 2997-3002. [CrossRef] [PubMed]

87. Llopis, J.; McCaffery, J.M.; Miyawaki, A.; Farquhar, M.G.; Tsien, R.Y. Measurement of cytosolic, mitochondrial, and Golgi pH in single living cells with green fluorescent proteins. Proc. Natl. Acad. Sci. USA 1998, 95, 6803-6808. [CrossRef] [PubMed]

88. Yang, Y.; Seidlits, S.K.; Adams, M.M.; Lynch, V.M.; Schmidt, C.E.; Anslyn, E.V.; Shear, J.B. A Highly Selective Low-Background Fluorescent Imaging Agent for Nitric Oxide. J. Am. Chem. Soc. 2010, 132, 13114-13116. [CrossRef] [PubMed]

89. Hilderbrand, S.A.; Lim, M.H.; Lippard, S.J. Dirhodium tetracarboxylate scaffolds as reversible fluorescence-based nitric oxide sensors. J. Am. Chem. Soc. 2004, 126, 4972-4978. [CrossRef] [PubMed]

90. Smith, R.C.; Tennyson, A.G.; Lim, M.H.; Lippard, S.J. Conjugated Polymer-Based Fluorescence Turn-On Sensor for Nitric Oxide. Org. Lett. 2005, 7, 3573-3575. [CrossRef] [PubMed]

91. Chen, X.; Tian, X.; Shin, I.; Yoon, J. Fluorescent and luminescent probes for detection of reactive oxygen and nitrogen species. Chem. Soc. Rev. 2011, 40, 4783-4804. [CrossRef] [PubMed]

92. Terai, T.; Urano, Y.; Izumi, S.; Kojima, H.; Nagano, T. A practical strategy to create near-infrared luminescent probes: Conversion from fluorescein-based sensors. Chem. Commun. 2012, 48, 2840-2842. [CrossRef] [PubMed]

93. Mao, Z.; Jiang, H.; Li, Z.; Zhong, C.; Zhang, W.; Liu, Z. An N-nitrosation reactivity-based two-photon fluorescent probe for the specific in situ detection of nitric oxide. Chem. Sci. 2017, 8, 4533-4538. [CrossRef] [PubMed]

94. Cunha, C.R.A.; Oliveira, A.D.P.R.; Firmino, T.V.C.; Tenório, D.P.L.A.; Pereira, G.; Carvalho, L.B.; Santos, B.S.; Correia, M.T.S.; Fontes, A. Biomedical applications of glyconanoparticles based on quantum dots. Biochim. Biophys. Acta Gen. Subj. 2017. [CrossRef] [PubMed]

95. Wang, S.; Han, M.-Y.; Huang, D. Nitric Oxide Switches on the Photoluminescence of Molecularly Engineered Quantum Dots. J. Am. Chem. Soc. 2009, 131, 11692-11694. [CrossRef] [PubMed]

96. Jin, H.; Heller, D.A.; Kalbacova, M.; Kim, J.-H.; Zhang, J.; Boghossian, A.A.; Maheshri, N.; Strano, M.S. Detection of single-molecule $\mathrm{H}_{2} \mathrm{O}_{2}$ signalling from epidermal growth factor receptor using fluorescent single-walled carbon nanotubes. Nat. Nanotechnol. 2010, 5, 302-309. [CrossRef] [PubMed]

97. Heller, D.A.; Jin, H.; Martinez, B.M.; Patel, D.; Miller, B.M.; Yeung, T.K.; Jena, P.V.; Hobartner, C.; Ha, T.; Silverman, S.K.; et al. Multimodal optical sensing and analyte specificity using single-walled carbon nanotubes. Nat. Nanotechnol. 2009, 4, 114-120. [CrossRef] [PubMed]

98. Jin, H.; Heller, D.A.; Kim, J.H.; Strano, M.S. Stochastic Analysis of Stepwise Fluorescence Quenching Reactions on Single-Walled Carbon Nanotubes: Single Molecule Sensors. Nano Lett. 2008, 8, 4299-4304. [CrossRef] [PubMed]

99. O'Connell, M.J.; Bachilo, S.M.; Huffman, C.B.; Moore, V.C.; Strano, M.S.; Haroz, E.H.; Rialon, K.L.; Boul, P.J.; Noon, W.H.; Kittrell, C.; et al. Band Gap Fluorescence from Individual Single-Walled Carbon Nanotubes. Science 2002, 297, 593-596. [CrossRef] [PubMed]

100. Dresselhaus, M.S.; Dresselhaus, G.; Eklund, P.C. Science of Fullerenes and Carbon Nanotubes; Academic Press: San Diego, CA, USA, 1996. [CrossRef]

101. Bachilo, S.M.; Strano, M.S.; Kittrell, C.; Hauge, R.H.; Smalley, R.E.; Weisman, R.B. Structure-Assigned Optical Spectra of Single-Walled Carbon Nanotubes. Science 2002, 298, 2361-2366. [CrossRef] [PubMed]

102. Giraldo, J.P.; Landry, M.P.; Faltermeier, S.M.; McNicholas, T.P.; Iverson, N.M.; Boghossian, A.A.; Reuel, N.F.; Hilmer, A.J.; Sen, F.; Brew, J.A.; et al. Plant nanobionics approach to augment photosynthesis and biochemical sensing. Nat. Mater. 2014, 13, 400-408. [CrossRef] [PubMed]

103. Kim, J.H.; Heller, D.A.; Jin, H.; Barone, P.W.; Song, C.; Zhang, J.; Trudel, L.J.; Wogan, G.N.; Tannenbaum, S.R.; Strano, M.S. The rational design of nitric oxide selectivity in single-walled carbon nanotube near-infrared fluorescence sensors for biological detection. Nat. Chem. 2009, 1, 473-481. [CrossRef] [PubMed]

104. Zhang, J.Q.; Boghossian, A.A.; Barone, P.W.; Rwei, A.; Kim, J.H.; Lin, D.H.; Heller, D.A.; Hilmer, A.J.; Nair, N.; Reuel, N.F.; et al. Single Molecule Detection of Nitric Oxide Enabled by d(AT)(15) DNA Adsorbed to Near Infrared Fluorescent Single-Walled Carbon Nanotubes. J. Am. Chem. Soc. 2011, 133, 567-581. [CrossRef] [PubMed] 
105. Iverson, N.M.; Barone, P.W.; Shandell, M.; Trudel, L.J.; Sen, S.; Sen, F.; Ivanov, V.; Atolia, E.; Farias, E.; McNicholas, T.P.; et al. In vivo biosensing via tissue-localizable near-infrared-fluorescent single-walled carbon nanotubes. Nat. Nanotechnol. 2013, 8, 873-880. [CrossRef] [PubMed]

106. Heller, D.A.; Baik, S.; Eurell, T.E.; Strano, M.S. Single-walled carbon nanotube spectroscopy in live cells: Towards long-term labels and optical sensors. Adv. Mater. 2005, 17, 2793-2799. [CrossRef]

107. Cherukuri, P.; Bachilo, S.M.; Litovsky, S.H.; Weisman, R.B. Near-infrared fluorescence microscopy of single-walled carbon nanotubes in phagocytic cells. J. Am. Chem. Soc. 2004, 126, 15638-15639. [CrossRef] [PubMed]

108. Schipper, M.L.; Nakayama-Ratchford, N.; Davis, C.R.; Kam, N.W.; Chu, P.; Liu, Z.; Sun, X.; Dai, H.; Gambhir, S.S. A pilot toxicology study of single-walled carbon nanotubes in a small sample of mice. Nat. Nanotechnol. 2008, 3, 216-221. [CrossRef] [PubMed]

109. Graff, R.A.; Swanson, J.P.; Barone, P.W.; Baik, S.; Heller, D.A.; Strano, S.M. Achieving individual-nanotube dispersion at high loading in single-walled carbon nanotube composites. Adv. Mater. 2005, 17, 980-984. [CrossRef]

110. Eroglu, E.; Gottschalk, B.; Charoensin, S.; Blass, S.; Bischof, H.; Rost, R.; Madreiter-Sokolowski, C.T.; Pelzmann, B.; Bernhart, E.; Sattler, W. Development of novel FP-based probes for live-cell imaging of nitric oxide dynamics. Nat. Commun. 2016, 7, 10623. [CrossRef] [PubMed]

111. Bush, M.; Ghosh, T.; Tucker, N.; Zhang, X.; Dixon, R. Transcriptional Regulation by the Dedicated Nitric Oxide Sensor, NorR: A Route towards NO Detoxification; Portland Press Limited: London, UK, 2011.

112. D'autréaux, B.; Tucker, N.P.; Dixon, R.; Spiro, S. A non-haem iron centre in the transcription factor NorR senses nitric oxide. Nature 2005, 437, 769-772. [CrossRef] [PubMed]

(C) 2018 by the authors. Licensee MDPI, Basel, Switzerland. This article is an open access article distributed under the terms and conditions of the Creative Commons Attribution (CC BY) license (http:/ / creativecommons.org/licenses/by/4.0/). 